\title{
FINANCIAL ADVICE, LITERACY, INCLUSION AND RISK TOLERANCE: THE MODERATING EFFECT OF UNCERTAINTY AVOIDANCE
}

\author{
Gentjan Çera', Khurram Ajaz Khan'2, Zuzana Rowland ${ }^{3}$, \\ Humberto Nuno Rito Ribeiro ${ }^{4}$
}

\footnotetext{
1 Tomas Bata University in Zlin, Faculty of Management and Economic, Czech Republic, ORCID: 0000-0002-9324-181X, cera@utb.cz;

2 Tomas Bata University in Zlín, Faculty of Management and Economic, Czech Republic, khan@utb.cz;

3 Institute of Technology and Business in České Budějovice, School of Expertness and Valuation, Czech Republic, ORCID: 0000-0002-7792-8873, rowland@mail.vstecb.cz;

$4 \quad$ University of Aveiro, ESTGA \& GOVCOPP, Portugal, hnr@ua.pt.
}

\begin{abstract}
The aim of this paper is to investigate the determinants of financial advice with a special focus on the cultural role in the influence of risk tolerance on seeking advice for financial issues. Financial literacy is covered by financial attitude, behaviour and knowledge. Financial inclusion is the other factor considered in the conceptual framework, as an indicator which can enhance both financial behaviour and financial advice. The research is based on primary data collected in two European nations, manifesting differences in culture, which gives the possibility to test the uncertainty avoidance role in the above relationship. This particular focus is the novelty of this work, as it sheds light on the importance of culture while designing policies with the aim to enhance individuals' financial literacy and advice. The hypotheses are tested by using Partial Least SquareStructural Equation Modelling (PLS-SEM) method. It was found that financial behaviour improves as financial inclusion gets better, along with financial attitude and knowledge. Furthermore, financial advice is positively influenced by financial inclusion and risk tolerance and partly by financial literacy. Additionally, findings demonstrate that culture does matter in explaining differences between countries. Culture in this paper is represented by uncertainty avoidance, as one of the Hofstede's culture dimension. Individuals from countries that manifest a very high preference for avoiding uncertainty reflect a negative relationship between risk tolerance and financial advice. The paper offers useful insights for policymakers and industry leaders in understanding the most influential factors on financial advice. This enables them to scheme policies and services aimed at equipping citizens with knowledge and skills to make the best use of their financial resources.
\end{abstract}

Keywords: Financial advice, financial inclusion, financial literacy, risk tolerance, culture.

JEL Classification: G53, D91.

APA Style Citation: Çera, G., Khan, K. A., Rowland, Z., \& Ribeiro, H. N. R. (2021). Financial Advice, Literacy, Inclusion and Risk Tolerance: The Moderating Effect of Uncertainty Avoidance. E\&M Economics and Management, 24(4), 105-123. https://doi.org/10.15240/tul/001/2021-4-007

\section{Introduction}

Not everyone has enough skills and abilities to tackle complex financial markets and make prudent financial decisions in uncommon situations. People worldwide have been using paid and unpaid sources for advice from someone they trust to overcome them.
Numerous studies have witnessed fruitful results from financial advisors in financial planning, such as retirement planning and wealth creation (Irving, 2012; Stolper \& Walter, 2017). The current issues, such as complexities of the financial market and difficulties arising out of the economic crisis, are becoming worrisome 
(Crotty, 2009; Taylor, 2011; Xiao \& O'Neill, 2016). The volatile economic environment and the problems of retirement financial security (Wang \& Shi, 2014) add to its severity. The most important of all is to know how to make a prudent economic decision in financial aspects (Lusardi \& Mitchell, 2014). The suffering resulting from the likelihood of losing money due to erroneous financial conclusions leads to financial anxiety (Cwynar et al., 2020). These issues are now becoming significant financial hurdles and trap individuals in economic losses through their unwise investment plans or poor debt management and frequently happens throughout the regions. It may be due to low financial literacy, as people lack financial literacy worldwide (Klapper et al., 2014). Therefore, to protect themselves from economic volatility and make prudent financial decisions, individuals may have two options only: either improve their financial literacy or look-out for someone's financial advice. It means someone else takes the financial decision on their behalf (Amaral \& Kolsarici, 2020; Yoong \& Hung, 2010).

Comparatively, financial advice can be avail easily, but developing financial literacy might be a long-term process and required lots of effort at the individual, government, and institutional levels. Therefore, financial advice seems a quick way out (Karabulut, 2012). However, now the question arises who will prefer financial advice, the one who has low or high financial literacy prefers high risk. There seems a need to determine the factors affecting financial advice, the key factors that push individuals towards financial advice. Hence the focus of the present study is to investigate the factors affecting financial advice-seeking behaviour. Since studies already found, individuals in developed countries prefer to take financial advice and draw their benefits (Stolper \& Walter, 2017). But why only in developed countries? It is because people in developed countries have higher financial literacy than emerging economics (Klapper et al., 2015). Displaying higher financial literacy might be a positive reason for seeking financial advice. However, this phenomenon is not much explored yet in other parts of the world except the USA and a few other countries (Stolper \& Walter, 2017). The existing literature reveals a lot about financial literacy and financial advice, but it is limited regarding how financial literacy can affect financial advice. The mixed connection between financial literacy and financial advice fails to bring out conclusive evidence to demarcate who prefers financial advice: one with higher or low financial literacy. It was found that the need for financial advice is more when the actual financial literacy level is low (Allgood \& Walstad, 2016; Khan et al., 2019; Yoong \& Hung, 2010). In those cases, financial advice proved to be helpful to make better financial decisions (Liu et al., 2019). In its support, quite a few studies state that individuals with better confidence in their financial literacy have less chance to seek financial advice (Kramer, 2016).

On its contrary, several studies support and claimed that people with better financial literacy have higher chances of seeking financial advice (Calcagno \& Monticone, 2015; Chauhan \& Dey, 2020; Collins, 2012; Cwynar et al., 2020; Pan et al., 2020). These mixed outcomes reveal a gap and give the present study the scope of how financial literacy can affect financial advice. Researchers explain financial literacy that is made of three components financial behaviour, financial attitude, and financial knowledge (Agarwalla et al., 2015; Atkinson \& Messy, 2012; Çera, Khan, Mlouk, et al., 2020; Garg \& Singh, 2018; Huston, 2010; Potrich et al., 2015, 2018; Santini et al., 2019). Supporting the role of financial literacy components, a few studies indicate that better results can be achieved from advice for those with less financial knowledge (Moreland, 2018; Nguyen \& Rozsa, 2019), which reflects the positive impact of financial knowledge on financial advice (Cliff et al., 2012). Since limited studies have investigated how each component of financial literacy affects financial advice individually, the present study's first objective is to examine the effect of financial behaviour, financial attitude, and financial knowledge on financial advice.

Another identified key factor is financial inclusion, which might affect financial advice. Financial institutions' advisory services can help their customers obtain better results (Hermansson, 2015), indicating the close connection between financial inclusion and financial advice. In England, financial inclusion is a part of the financial capability strategy to increase financial services access to promote financial advice among deprived segments (Atkinson \& Messy, 2013). It was also traced that improving financial inclusion through digital finance can strengthen the relationship between service providers and users (Ozili, 
2018). Being financially inclusive does affect individuals' financial advice? The literature signals a close connection between financial inclusion and financial advice has become part of the financial system that can open doors for the financial advisory. However, the studies in this regard are not enough to reveal financial inclusion's impact on financial advice. Thus, another objective of the present study to determine the impact of financial inclusion on financial advice.

Another key closed looking aspect is risk tolerance. Based on the concept of an individual's risk preferences, does it affect an individual's financial advice-seeking behaviour? Studies state that risk tolerance is a crucial topic in financial planning (Amaral \& Kolsarici, 2020; Hanna et al., 2011). Financial planners are the one who gives financial advice and evaluates the clients risk tolerance level (Callan \& Johnson, 2002). Humans cannot process all the information rationally, and emotions influence their decisions (Lerner et al., 2004). Due to this relationship, they may fail to make optimal financial decisions. Trust in advice is closely connected with an individual's risk-taking willingness. Trust is an important determinant of financial advice-seeking behaviour (Tang \& Lachance, 2012). Financial advice is given based on assessing and understanding the individuals' risk tolerance level (Callan \& Johnson, 2002). It means, when an individual cannot assess his risk tolerance level, he or she might need financial advice, or those who are willing to take high risk may need financial advice and likewise. All these signals that an individual's risk tolerance may affect financial advice. In this regard, it becomes imperative to investigate the impact of risk tolerance on financial advice.

Everything exists in an environment, so as a human being, and every individual belongs to a culture. Studies found that there is a link between culture, money, and risk tolerance (Henchoz et al., 2019; Statman, 2010). Culture has a substantial influence on people's judgment and decision making, which cannot be ignored. Culture affects how people behave and how they think, how they convey views about others and the environment. Above all, how individuals assess and choose between various alternatives (Odongo, 2016) whether to choose financial advice or not. A collective society may prefer advice from others, but on its contrary individualistic may not or less (LeFebvre \& Franke, 2013). Therefore, culture might influence the individual's risk tolerance and financial advice seeking choice.

A thorough understanding of the prevailing market conditions is crucial for making the right financial product choice and minimising loss (Braunstein \& Welch, 2002). Hence, seeking competent financial advice before selecting any financial product is always a good option (Stolper \& Walter, 2017). Studies have tried to showcase the role of financial literacy regarding financial advice (Calcagno \& Monticone, 2015; Kramer, 2016; Pan et al., 2020; Př́vara \& Kiner, 2020; Stolper \& Walter, 2017; Von Gaudecker, 2015). Individuals may prefer financial advice to take the calculated risk since good financial advice plays a significant role in bringing financial stability and well-being. It also improves financial satisfaction (Winchester \& Huston, 2015) because consumers prefer financial advice services because of their known psychological and financial benefits (Westermann et al., 2020). So much has been covered so far, but no prior study, to the extent of the authors' knowledge, has covered financial literacy components, financial inclusion, and risk tolerance along with culture effect in an integrated framework to determine its impact on financial advice.

The critical contribution of the present study is to investigate the determinants of financial advice. Explored the factors which are not addressed yet as a determinant of the financial advice. The present study's concentration is on Europe's emerging economies since most financial advice studies have been conducted in the USA and are very limited in Europe (Stolper \& Walter, 2017). Also, individuals in European countries are turning up for advice towards financial intermediaries because they are the critical source of financial information (Calcagno \& Monticone, 2015). The present study can be informative for financial advisors, government agencies, and financial service providers to develop effective strategies to support consumer financial planning, safeguard from financial threats and investment decisions.

\section{Literature Review}

From routine financial decisions, the smallest to long term financial retirement planning decisions, the whole story revolves around how an intelligent financial decision can be 
made. Financial decision making determines individuals' gain, loss, financial security, stability, and failure. Nobody prefers financial loss, failure, and instability. Shreds of literature reveal that financial advice is getting considerable attention in current years (Chauhan \& Dey, 2020; Khan \& Akhtar, 2020; Moreland, 2018; Stolper, 2018; Stolper \& Walter, 2017; Von Gaudecker, 2015; Worimegbe et al., 2020). It was found that financial advice can help to advance and polish individuals' financial decision making (Kim et al., 2018). Many individuals pursue expert advice for financial decision-making. In return, it reflects its usefulness (Stolper \& Walter, 2017). The previous studies found mixed results on who prefers financial advice attract further investigation and the growing importance of financial advice and its role in improving individuals' financial performance (Lusardi \& Mitchell, 2014). Studies indicate that financially capable individuals, must-have advice, and guidance to achieve financial stability (Sherraden et al., 2015). The importance of financial advice matters even more where there is a low level of financial ability (Georgarakos \& Inderst, 2011) that prevails in many parts of the world. Hence, in order to understand what attracts and affects individuals to use financial advice. The study links how financial behaviour, financial knowledge, financial attitude, financial inclusion, and risk tolerance positively encourage individuals for financial advice in a specific cultural environment.

\subsection{Hypotheses Development}

Financial attitude, financial knowledge, and financial behavior are the essential components of financial literacy (Atkinson \& Messy, 2012; Belás et al., 2016; Fernandes et al., 2014; Lusardi \& Mitchell, 2014; OECD, 2013; Potrich et al., 2015). Individuals with a higher level of financial literacy recognise the value of financial advice (Calcagno \& Monticone, 2015; Chauhan \& Dey, 2020; Collins, 2012; Cwynar et al., 2020; Pan et al., 2020). It indicates that financial literacy elements positively impact financial advice. Financial decision making is always critical for any individual because it requires financial knowledge, the right financial attitude, and favourable financial behavior. Generally, the lack of adequate financial literacy is a significant problem worldwide (Klapper et al., 2015) to make wise financial choices. Moreover, not sound financial decision making can bring financial havoc and erase all hard-earned and saved money. Since higher financial literacy is favourable for financial advice-seeking and improvement in financial decision making, it reflects its positive effect on financial adviceseeking behaviour. Besides, the countries' financial regulations also encourage financial entities to give their clients financial advice and bring them under the financial system's ambit through various financial literacy enhancement programs. These programs can also influence the attitude, knowledge, and behaviour of individuals towards financial advice.

Financial advice is an easy and quick option for an immediate solution (Karabulut, 2012) to avoid above mentioned situations. Since financial advice includes comparing risk and returns on financial assets; therefore, a certain amount of financial literacy is required (Pan et al., 2020). The individuals either must improve their financial literacy or use financial advice as a substitute. Either an individual learns and promotes his/her financial proficiency or can avail advice for better financial decisions, and dogged the efforts to be taken for learning (Calcagno \& Monticone, 2015). Financial advice is about delegation of trust in advisors' services who can make better financial decisions. Instead of stressing enhancing financial education to improve financial decision making, financial advice can be an alternative way to enhance quality financial decisions (Stolper \& Walter, 2017). Prior studies found that financial advice improves financial decisions (Collins, 2012; Kim et al., 2018; Moreland, 2018; Westermann et al., 2020). Since it is the choice of an individual to look-out for financial advice, it depends on an individual's financial attitude, behaviour, and knowledge. Studies support with their findings that seeking financial advice is related to financial attitude and individual behaviour (Moreland, 2018). To build an individual's financial ability, individuals musthave advice and guidance to plan and make steady financial decisions (Sherraden et al., 2015). This fact highlights the role of financial literacy components in financial advice, which cannot be ignored.

Attitude is about the individuals' willingness to undertake any particular action about a task, to do or not. It is a belief behind the individuals' motivation to take a specific action (Ajzen, 1991). The individuals always assess their behaviour outcomes, and that assessment 
forms the individuals' attitudes (Yong et al., 2018). Financial attitude can be understood as an individual leaning towards financial matters. Financial attitude is an individual's way of approaching financial issues and decisionmaking (Rai et al., 2019). It concerns an individual's opinion and mindset, how people manage their financial affairs and make financial decisions. It is about the mindset, opinion, and judgments that form the attitude and are related to the human mindset. That is why it affects individuals' financial decision-making (Arifin, 2018). Financial attitude is related to individuals' economic beliefs. Interestingly, others' opinions can influence individual decision making, as well. Advisors' advice can help decision-makers regarding the unattended substitutions and unintentional consequences (Yaniv, 2004). Positive financial advice can make a better financial decision, and it might also develop a positive financial attitude towards financial advice. Besides this, an individual's attitude can determine an individual's acceptance and willingness of financial advice.

The second component of financial literacy is behaviour. The theory of planned behaviour explains that attitude results in behaviour formation (Ajzen, 1991). There is a close association between attitude and behaviour. Various scholarly articles indicate that financial attitude is crucial in comprehending individuals' financial behavior (Castro-González et al., 2020; Vieira et al., 2019; Yap et al., 2018; Yong et al., 2018). Being one of the influential of the individuals' financial behavior, the financial attitude has a considerable impact on financial decision making (Robb \& Woodyard, 2011; Yap et al., 2018). Subsequently, the indication from studies also exposes that changing selfbeliefs is associated with changing financial behaviours (Serido et al., 2013), reflecting the role of financial attitude. Other studies reinforce this association and find attitudes and behaviours linked to each other (Joo \& Grable, 2004; Sample \& Warland, 2018) and financial attitude has a positive linkage with financial behaviour (Fünfgeld \& Wang, 2009; Glasman \& Albarracín, 2006; Vieira et al., 2019).

Furthermore, the researchers give much importance to understanding individuals' financial behaviour since it is critical to individuals' financial planning (Lusardi \& Mitchelli, 2007). Consumers' behavioural factors influence the choice of different financial services (Beckett et al., 2000), and these behavioural factors might affect the choice of financial advisory services as well. Rational financial behaviour has a positive effect on financial advice. However, in changing situations, complex economic circumstances, and the dynamic environment, it is worth examining how financial literacy elements affect financial advice in the interval of times. Hence based on the discussion, the following hypotheses have been framed:

H1a: Financial attitude positively affects financial behaviour.

H1b: Financial attitude positively affects financial advice.

H2: Financial behaviour positively affects financial advice.

An individual's financial knowledge is a crucial component for improved financial decision making. Existing literature reveals that financial knowledge is about understanding basic financial concepts (Huston, 2010). Evidence also exposed a strong link between the individuals' financial knowledge and financial practices. It empowers individuals to schedule their payment commitments, emergency savings funds, make judicious investments, and set optimal financial goals (Chu et al., 2017; Randáková \& Bokšová, 2016; Shkvarchuk \& Slav'yuk, 2019). Further delving reveals that financial knowledge affects individuals' financial behaviour and decision-making, and they are associated with each other (Allgood \& Walstad, 2016; Kalmi, 2018) in both long term and short term horizons (Henager \& Cude, 2019; Kim et al., 2019; Zamir, 2019). The discussion establishes a reasonable connection between financial knowledge and financial behaviour. Another relation to examining is how financial knowledge affects financial advice. Since the previously found mixed results from the studies indicate that both categories of individuals who are good at financial literacy and those who have low financial literacy seek financial advice. This discussion gives insight that financial advice is needed in all situations. Whether an individual has higher/lower financial literacy seeks financial advice. Being part of financial literacy, financial knowledge may have a direct effect on financial advice. Financial knowledge, either subjective or objective, are positively related to financial advice usage, precisely regarding saving and investing, insurance and tax planning, and many more (Cliff et al., 2012). The current challenges of financial markets, 
such as its complex system and complexities in products and services, so on, have made the financial advice necessary for individuals' decision-making.

H3a: Financial knowledge positively affects financial behaviour.

H3b: Financial knowledge positively affects financial advice.

Financial literacy gives individuals the ability to make favourable financial decisions. However, internal ability alone may not be enough (Johnson \& Sherraden, 2007). An individual needs external opportunity, as well. One such opportunity is to be financially inclusive (Johnson \& Sherraden, 2007; Sherraden \& Ansong, 2016) to bring individuals under the financial system's ambit. Organisation for Economic Corporation and Development (OECD, 2013) explains that financial inclusion concerns the level of awareness, availability, and accessibility of financial products and services to individuals. People must have the opportunity to avail themselves of financial services easily and conveniently. Poor financial inclusion restricts individuals from reaching and avail financial services required for saving, investment, and long-term planning. Studies explain that financial inclusion happens when an individual can have timely, cost-effective, easily accessible, safe, easy to use and, of course, reliable financial services, leading to financial inclusion (Aprea et al., 2016; Sherraden, 2013). Enhanced financial inclusion improves people's ability to make better investment decisions and safeguard from market risks. It was also found that financial inclusion positively improves individuals' savings because it gives easy access to banking services (Kempson et al., 2013).

Financial inclusion empowers individuals to get financial services easily accessible. This easiness supports individuals in their financial planning and decision-making because of its accessibility and availability. Previous studies found that financial inclusion helps individuals in asset accumulation (Reyers, 2019). Availability and accessibility of financial services equip individuals to look for the best possible financial services for making the most appropriate financial and retirement plans. A recent study found that access and quality of financial inclusion are among the features that affect individuals' household and debt behaviour (Riau, 2019). Therefore, examining the impact of financial inclusion on financial behaviour will give a new insight.

Financial services accessibility and availability help individuals utilise the financial service for their financial planning, savings, and investments for both short-term and longterm goals. It has been found that advice plays a vital role in retailing financial services, such as mortgages, investments, and many more (Inderst \& Ottaviani, 2012). Many times, for consumers, it is not easy to comprehend complex financial products. In those cases, financial advice can play an essential role in financial services retailing (Inderst \& Ottaviani, 2012). Therefore, there seems a link between financial inclusion and financial advice. An individual's anxiety towards financial consultant support need is based on the level of knowledge they have about financial planning practices (Gerrans \& Hershey, 2014). Therefore, it might be possible that people may approach towards financial service providers to seek advice too. Since financial inclusion and financial advice are part of the financial system, somehow, financial advice and financial inclusion are also related, as financial advice comes from financial inclusion. Also, the countries' financial regulations encourage financial entities to give financial advice to their clients, bring them under the ambit of the financial system through various financial literacy enhancement programs, technically called financial inclusion. These regulations can also influence the behaviour of individuals and financial advice. The outcomes will add to the limited available literature on financial inclusion and financial advice. Based on the above discussion, the following hypothesis has been framed as to whether financial inclusion positively affects financial advice.

H4a: Financial inclusion positively affects financial behaviour.

H4b: Financial inclusion positively affects financial advice.

Financial advice has to do with making better investment choices, saves time and does risk and return trade-off to minimise risk and maximise return. The fundamental concept states high returns from high risk, but this is complicated. To handle complications, one may prefer financial advice. Financial risk tolerance is a weighty issue and a significant factor in several financial decisions (Grable, 1999; Matis et al., 2013). Risk tolerance is the amount of 
risk a person is willing to accept (Callan \& Johnson, 2002). Evaluation of financial risk and how much risk the individuals are willing to take is an essential exercise before making any financial decisions as it affects the risk of losing money and returns. Studies found a positive connection between investment decisions and individuals' risk tolerance and customer trust and relationship trust in the services, have a positive association with customer level of financial literacy and risk tolerance (Nguyen et al., 2016). Higher risk preferences raise higher anticipation for wealth build-up. A readiness to take risks is supposed to be a requirement for accruing wealth (Yao et al., 2005). However, there is a likelihood that wealth may decline if an individual mishandles her/his financial environment (Grable \& Roszkowski, 2008). To avoid loss and enhance the fund's returns and safety, an individual may prefer financial advice to have calculated risk. This fact reflects a connection between the financial advisor and customer risk tolerance. A study recently found a significant relation between individual's level of risk tolerance and propensity to seek financial advice. It explains that if individuals have a higher risk tolerance level, they have a higher chance of looking out for financial advice (Amaral \& Kolsarici, 2020). Whether individuals prefer financial advice when they are willing to take a high risk or have minimal risk has not received much attention yet. However, it seems radical to be explored to understand how an individual's risk tolerance can affect individual financial advice.

H5: Risk tolerance positively affects financial advice.

\subsection{Moderating Effect of Uncertainty Avoidance}

Culture is a collective phenomenon, as it is at least partially shared with those who live or lived in the same social environment where it was learned (Hofstede et al., 2010). The collective programming of the mind discriminates followers of one group or type of people from others. It means people from two different cultures may have a different mindset, different behaviour, and personality trait. Mueller and Thomas (2001) explained that culture is the basic system of values specific to a particular group or community, influences personality traits, and develops specific behaviour in the individuals. Since the entire system of values is unique to a specific group or society affects particular personality traits development and stimulates individuals to engage in behaviours. Culture not only explains the similarities but also identifies the contrasts in behaviour (Smith et al., 2002). It signals that there could be similarities and dissimilarities between cultures, and the contrast between them will be an excellent scale to understand them individually. According to Hofstede et al. (2010), different nations reflect different cultures, and they can classify into a distinct group the base of different dimensions. The present study examined the moderating role of culture in the relationship between risk tolerance and financial advice.

The present study assumed that the relationship between risk tolerance and financial advice is jointly affected by two major cultural factors, explicitly, individualism-collectivism and uncertainty avoidance (Hofstede \& Hofstede, 1991). When it comes to analysing trust and risk preference, based on society orientation towards certainty preferences, uncertainty avoidance is considered as moderator by many studies on the society orientation (Çera, Khan, Belas, et al., 2020; Jang et al., 2018). According to Hofstede et al. (2010), uncertainty avoidance refers to the extent to which the members of a culture feel threatened by vague or indefinite circumstances. It is about the ambiguity which makes the individuals susceptible. High uncertainty avoidance cultures dodge ambiguous situations and reflect a lower tolerance towards uncertainty than individuals in low uncertainty avoidance cultures. Individuals in such cultures look for more certainty, which can make actions interpretable and expectable. People from low uncertainty avoidance cultures reflect lower anxiety, controlled emotions, relatively more comfortable with ambiguity, more tolerant of diversity, and more open to seeking novelty and convenience, and the people in high uncertainty avoidance have opposites features (Hofstede, 2001). Hofstede (2001) also stresses that uncertainty leads to risk and anxiety, leading to fear, differentiated that $\mathrm{UA}$ is different from risk avoidance. Therefore, uncertainty avoidance is distinguished from risk avoidance, which indicates that the low uncertainty avoidant individuals might prefer a higher risk option to lessen their uncertainty and vice-versa. In support of the present study, tangible supports can be found from the studies, indicating that uncertainty negatively 
affects risk-taking (Kreiser et al., 2010). Further supported by Statman (2010), high uncertainty avoidance has a lower risk tolerance than lower uncertainty avoidance nations. Also, socioeconomic and demographics influence the risk tolerance levels (Jeong \& Hanna, 2004), which are part of society and culture. Therefore:

H6: The relationship between risk tolerance and financial advice is weaker in countries with high uncertainty avoidance.

Since uncertainty avoidance is a concern with the degree of certainty preference, how much risk individuals are willing to tolerate, their preference of certainty over uncertainty, and how much control they prefer over uncertain future events. Consider the cultural difference between Poland and Spain, where Poland reflects higher uncertainty avoidance compare to Spain. Hence, one with lower risk avoidance may prefer financial advice, and the other may take more risk without much guidance from the advisors. Countries from the west and the east reflect many dissimilarities. Hence, it would be logical to examine the moderating effect of uncertainty avoidance. Therefore, to understand the influence of culture on risk tolerance's effect on financial advice, the uncertainty avoidance dimension has been chosen.

\section{Methods and Procedures}

To test the proposed conceptual framework, a questionnaire was initially designed mainly based on the National Financial Capability Study (NFCS) (FINRA, 2012). Before the data collection, a pilot test was done. The data were collected during June and July 2019. To get to the respondents, university alumni databases were used (the University of Huelva in Spain and the University of Warsaw in Poland). An email was sent to alumni students asking to provide the contacts of a family member who recently had a birthday. A link of the questionnaire was then sent to this family member asking him/her to fill it in. All in all, 402 valid questionnaires were collected, which is above the minimum sample size (Bagozzi \& Yi, 2012). Tab. 1 shows the profile of the sample.

The research was done in two countries because one of the aims was to capture the effect of culture on the relationship between risk tolerance and financial advice. Based on the literature review, uncertainty avoidance may moderate this association. Therefore, the above relationship can be tested by comparing countries that manifest differences in culture (Hofstede et al., 2010). Poland and Spain are two countries with different levels in cultural dimensions, although being part of the Europe

\section{Fig. 1: Theoretical model}

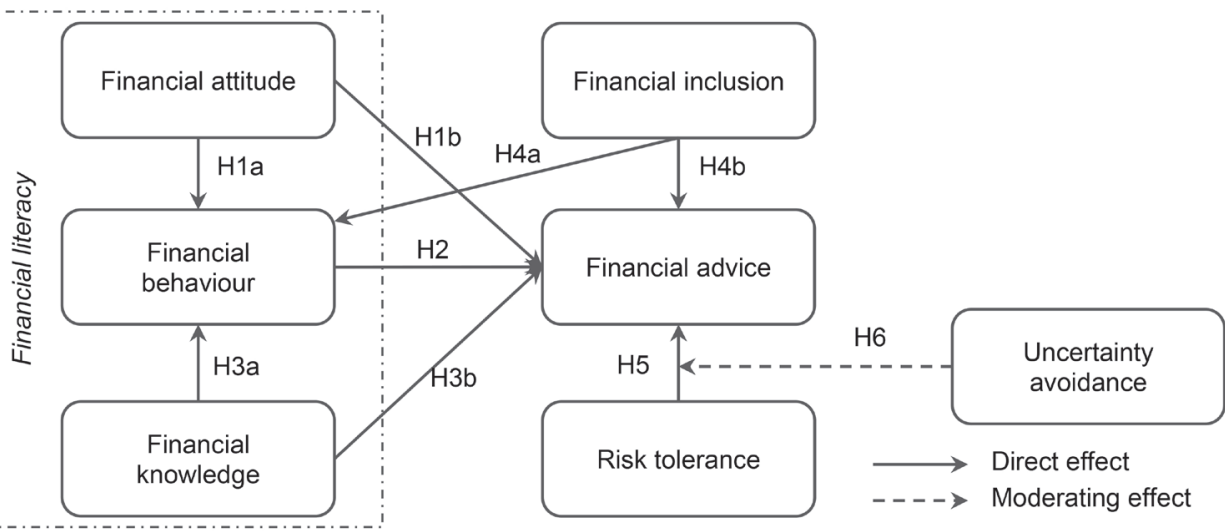




\section{Tab. 1: Sample profile}

\begin{tabular}{|c|c|c|c|c|}
\hline Variable & Category & $\begin{array}{c}\text { Poland } \\
(n=200)\end{array}$ & $\begin{array}{c}\text { Spain } \\
(n=202)\end{array}$ & $\begin{array}{c}\text { Total } \\
(n=402)\end{array}$ \\
\hline Gender & Female & $57.5 \%$ & $70.3 \%$ & $63.9 \%$ \\
\hline Age & Mean (standard deviation) & $26.8(7.31)$ & $28.6(6.75)$ & $27.7(7.08)$ \\
\hline \multirow[t]{6}{*}{ Region } & North & $18.0 \%$ & $32.7 \%$ & $25.4 \%$ \\
\hline & Central & $21.5 \%$ & $15.5 \%$ & $18.4 \%$ \\
\hline & Capital city & $10.0 \%$ & $9.9 \%$ & $9.9 \%$ \\
\hline & South & $20.0 \%$ & $24.3 \%$ & $22.2 \%$ \\
\hline & East & $19.5 \%$ & $5.9 \%$ & $12.7 \%$ \\
\hline & West & $11.0 \%$ & $11.9 \%$ & $11.4 \%$ \\
\hline \multirow{2}{*}{$\begin{array}{l}\text { Leaving } \\
\text { settlement }\end{array}$} & Urban area & $53 \%$ & $79 \%$ & $66 \%$ \\
\hline & Rural area & $47 \%$ & $21 \%$ & $34 \%$ \\
\hline \multirow[t]{4}{*}{ Income } & Up to 900 EUR (2,000 PLN) & $27.0 \%$ & $28.2 \%$ & $27.6 \%$ \\
\hline & $900-1,500$ EUR $(2,000-4,000$ PLN) & $51.5 \%$ & $24.8 \%$ & $38.1 \%$ \\
\hline & 1,500-2,000 EUR $(4,000-7,500$ PLN) & $17.0 \%$ & $36.1 \%$ & $26.6 \%$ \\
\hline & Above 2,000 EUR (7,500 PLN) & $4.5 \%$ & $10.9 \%$ & $7.7 \%$ \\
\hline
\end{tabular}

Union and dominance of Roman Catholic believers. Poland has a very high preference for avoiding uncertainty as its score on uncertainty avoidance is 93 , while Spain scores 86 on the same dimension.

All constructs were measured as selfreported, and they are summarised in Tab. 2. Each of the proposed constructs' items was a five-point Likert-type scale $(1=$ strongly disagree, 5 = strongly agree). In addition, Tab. 2 reports the measurement model for all variables included in the conceptual framework. The lowest Cronbach's alpha was found 0.784 (financial inclusion), which is well above the standard threshold of 0.70 , meaning sound scale reliability. All items loadings were reported above 0.70, and there was no multicollinearity since the VIF coefficients were lower than the critical value of 3 .

\section{Tab. 2:}

\section{Measurement model - Part 1}

\section{Statements per each construct}

LO $\quad$ VIF

Financial attitude $(C A=0.786 ; C R=0.862)$ Source: Atkinson \& Messy, 2011

It is important to set goals for the future.

I pay my bills on time.

I keep a close personal watch on my financial affairs.

\begin{tabular}{|l|l|l|l}
\hline I am prepared to risk some of my own money when saving or making an investment. & 0.726 & 1.448 \\
\hline
\end{tabular}

Financial advice $(C A=0.812 ; C R=0.869)$ Source: FINRA, 2012

\begin{tabular}{l|c|c}
\hline I think financial advice is helpful. & 0.725 & 1.507 \\
\hline $\begin{array}{l}\text { I consider the other's opinions in decision making (buying, investing, savings, } \\
\text { borrowings, etc). }\end{array}$ & 0.789 & 1.755 \\
\hline Consultation is essential in dealing with financial issues. & 0.767 & 1.626 \\
\hline
\end{tabular}


I think financial advice will help me to achieve financial expectations in a better way than an alone decision.

I would trust financial professionals and accept what they recommend.

Financial behaviour $(C A=0.842 ; C R=0.884)$ Source: Joo \& Grable,

0.719

1.554

2000; and Potrich et al., 2016

I take notes and control my personal expenses (e.g., expense and revenue spreadsheet).

I establish financial targets for the long term that influence the management of my expenses.

\begin{tabular}{l|l|l}
\hline I follow a weekly or monthly plan for expenses. & \multicolumn{2}{l}{} \\
\hline I compare prices when buying something. & 0.734 & 1.632 \\
\hline I analyse my financial situation before a big purchase. & 0.713 & 1.593 \\
\hline I have plans to achieve my financial goals (retirements, savings, investments, etc). & 0.776 & 1.859 \\
\hline Financial inclusion (CA = 0.784; CR = 0.863) Source: Zins \& Weill, 2016 & 0.789 & 1.976 \\
\hline For me, banking services are still expensive [r]. & 0.774 & 1.337 \\
\hline I lack enough documentation to have a bank account [r]. & 0.760 & 1.620 \\
\hline One bank account is enough in my family [r]. & 0.807 & 1.778 \\
\hline I do not need financial services [r]. & 0.763 & 1.587 \\
\hline Financial knowledge (CA = 0.793; CR = 0.866) Source: Robb \& Woodyard, 2011; and Perry \& Morris, 2005 \\
\hline Investing in different assets reduces risk. & 0.793 & 1.542 \\
\hline An Investment with a high return is likely to be highly risky. & 0.728 & 1.377 \\
\hline High inflation means that the cost of living is increasing rapidly. & 0.814 & 1.843 \\
\hline $\begin{array}{l}\text { If the price goes up rapidly, the money people have in saving accounts could lose } \\
\text { much of its value. }\end{array}$ & 0.805 & 1.748 \\
\hline Risk tolerance (CA = 0.789; CR = 0.863) Source: Joo \& Grable, 2004 & & \\
\hline In terms of investing, safety is more important than returns. & 0.804 & 1.597 \\
\hline When I think of the word 'risk' the term 'loss' comes to mind immediately. & 0.763 & 1.495 \\
\hline Making money from a risky investment is based on luck. & 0.782 & 1.650 \\
\hline Investing is too difficult to understand. & 0.780 & 1.668 \\
\hline
\end{tabular}

Source: own

Note: $\mathrm{LO}=$ loading; $\mathrm{CA}=$ Cronbach's alpha; $\mathrm{CR}=$ composite reliability; VIF = variance influence factor; $[\mathrm{r}]=$ reverse.

Excluding financial knowledge, all the Heterotrait-Monotrait coefficients (Henseler et al., 2015) were below the conservative threshold of 0.85 , indicating that all constructs were distinct one from another. The HTMT coefficient of financial knowledge is at the edge of the above threshold. Given the importance of this variable to the whole conceptual framework and reflecting an HTMT coefficient very close to the conservative threshold, it was decided not to drop financial knowledge from the model. Therefore, it was concluded that the discriminant validity is established for this research.

\section{Results}

Questionnaire design and Harman's single factor test were selected as two techniques to investigate common method bias in the research (Podsakoff et al., 2003). The title for each set of items was not shown in the questionnaire. According to Harman's singlefactor test, a significant level of common method variance exists when a single factor emerges or captures more than $50 \%$ of the variance (Podsakoff et al., 2003). The result of the principal axis factoring showed that this single factor explained $37.087 \%$ of the total 


\begin{tabular}{l|c|c|c|c|c|c} 
& FA & FAD & FB & FI & FK & RT \\
\hline FA & - & 0.623 & 0.668 & 0.467 & 0.684 & 0.587 \\
\hline FAD & 0.776 & - & 0.673 & 0.511 & 0.580 & 0.599 \\
\hline FB & 0.813 & 0.809 & - & 0.520 & 0.650 & 0.660 \\
\hline FI & 0.579 & 0.620 & 0.621 & - & 0.511 & 0.598 \\
\hline FK & 0.860 & 0.718 & 0.786 & 0.632 & - & 0.568 \\
\hline RT & 0.739 & 0.744 & 0.802 & 0.755 & 0.713 & - \\
\hline
\end{tabular}

Source: own

Note: Correlation coefficients are above the diagonal, while HTMT coefficients are below that. FA = financial attitude; $\mathrm{FK}$ = financial knowledge; $\mathrm{FB}=$ financial behaviour; $\mathrm{FI}=$ financial inclusion; $\mathrm{FAD}=$ financial advice; $\mathrm{RT}=$ risk tolerance.

variance. Accordingly, there was no threat of common method variance in this research.

To test the proposed conceptual model, partial least squares structural equation modelling (PLS-SEM) was performed (Hair et al., 2017). PLS-SEM was used because of the following reasons: firstly, the current research requires latent variable scores to test the relationships and, secondly, the composed variables were not normally distributed (Hair et al., 2019). All composed variables were formed using reflective indicators. PLS-SEM was performed in SmartPLS 3.0 (Ringle et al., 2015), with 5,000 iterations of resampling.

The results of PLS-SEM for the proposed theoretical model are summarised in Tab. 4. Besides the financial constructs, some individual demographics were included in the model

\section{Tab. 4: Hypotheses testing}

\begin{tabular}{l|l|c|c|c|c} 
Hypothesis & \multicolumn{1}{|c|}{ Path } & $\boldsymbol{\beta}$ & $\boldsymbol{t}$ & VIF & Supported? \\
\hline $\mathrm{H} 1 \mathrm{a}$ & $\mathrm{FB} \leftarrow \mathrm{FA}$ & 0.378 & $7.454^{* * *}$ & 1.947 & Yes \\
\hline $\mathrm{H} 3 \mathrm{a}$ & $\mathrm{FB} \leftarrow \mathrm{FK}$ & 0.292 & $5.471^{* * *}$ & 2.063 & Yes \\
\hline $\mathrm{H} 4 \mathrm{a}$ & $\mathrm{FB} \leftarrow \mathrm{FI}$ & 0.195 & $4.510^{* * *}$ & 1.403 & Yes \\
\hline $\mathrm{H} 1 \mathrm{~b}$ & $\mathrm{FAD} \leftarrow \mathrm{FA}$ & 0.174 & $3.568^{* * *}$ & 2.494 & Yes \\
\hline $\mathrm{H} 2$ & $\mathrm{FAD} \leftarrow \mathrm{FB}$ & 0.288 & $4.548^{* * *}$ & 2.590 & Yes \\
\hline $\mathrm{H} 3 \mathrm{~b}$ & $\mathrm{FAD} \leftarrow \mathrm{FK}$ & 0.060 & 1.124 & 2.334 & No \\
\hline $\mathrm{H} 4 \mathrm{~b}$ & $\mathrm{FAD} \leftarrow \mathrm{FI}$ & 0.117 & $2.461^{*}$ & 1.753 & Yes \\
\hline $\mathrm{H} 5$ & $\mathrm{FAD} \leftarrow \mathrm{RT}$ & 0.166 & $2.650^{* *}$ & 2.415 & Yes \\
\hline & $\mathrm{FAD} \leftarrow$ Uncertainty avoidance & -0.028 & 0.618 & 1.836 & - \\
\hline $\mathrm{H} 6$ & $\mathrm{FAD} \leftarrow$ Uncertainty avoidance ${ }^{*} \mathrm{RT}$ & -0.087 & $1.979^{*}$ & 1.328 & Yes \\
\hline & FAD $\leftarrow$ Education & 0.052 & 1.366 & 1.163 & - \\
\hline & FAD $\leftarrow$ Income & 0.065 & 1.484 & 1.371 & - \\
\hline & FAD $\leftarrow$ Gender & 0.045 & 1.238 & 1.063 & - \\
\hline
\end{tabular}

Source: own

Note: $F A$ = financial attitude; $F K=$ financial knowledge; $F B=$ financial behaviour; $F I=$ financial inclusion; $F A D=$ financial advice; RT = risk tolerance; records from Poland are coded with 1, and those from Spain with 0; VIF = variance influence factor; $\mathrm{R}$ square for $\mathrm{FB}=0.543$; $\mathrm{R}$ square for $\mathrm{FAD}=0.562 ;{ }^{*},{ }^{* *}$, *** refer to $95 \%, 99 \%$ and $99.9 \%$, respectively. 
as control variables to avoid potential causal influence on financial advice. The model explains $54.3 \%$ and $56.2 \%$ of the variance in financial behaviour and financial advice, respectively. There were no multicollinearity issues since none of the variables reflected a variance influence factor higher than the threshold of 3.

The evidence supports the proposed determinants of financial behaviour. Hence, financial behaviour is positively affected by financial attitude $(\beta=0.378 ; t=7.454$; $p<0.001)$, financial knowledge $(\beta=0.292$; $t=5.471 ; p=0.001)$ and financial inclusion $(\beta=0.194 ; t=4.510 ; p<0.001$ ) (see Tab. 4). Therefore, $\mathrm{H} 1 \mathrm{a}, \mathrm{H} 3 \mathrm{a}$, and $\mathrm{H} 4 \mathrm{a}$ were supported.

Regarding the determinants of financial advice, it was found that, beside financial knowledge, all other financial constructs positively impacted financial advice (see Tab. 4). Thus, financial advice is significantly and positively affected by financial attitude ( $\beta=0.060, t=1.124, p>0.05)$ and financial behaviour $(\beta=0.060 ; t=1.124 ; p>0.05)$, so supporting $H 1 b$ and $H 2$. Moreover, financial advice is positively influenced by financial inclusion $(\beta=0.117 ; t=2.461 ; p<0.05)$ and risk tolerance $(\beta=1.66 ; t=2.650 ; p<0.01)$. These results fail to reject $H 4 b$ and $H 5$. However, analysis demonstrates that financial knowledge did not impact financial advice ( $\beta=0.060 ; t=1.124 ; p>0.05)$, leading to the rejection of $H 3 b$.

This work also incorporates in its conceptual model the moderating effect of uncertainty avoidance on the relationship between risk tolerance and financial advice. The moderating effect was tested through PLS-SEM, and its result is shown in Tab. 4. It was found that uncertainty avoidance does statistically moderates the above linkage $(\beta=-0.087$; $t=1.979 ; p<0.05)$. Thus, substantial evidence was found in supporting the hypothesised moderating role of uncertainty avoidance in driving the influence of risk tolerance on financial advice, $\mathrm{H} 6$.

Fig. 2 illustrates the moderating effect of uncertainty avoidance on the effect of risk tolerance on financial advice. As can be seen, the two curves reflected not the same direction. Moving from low to high-risk tolerance, individuals from Poland reflected lower financial advice. This result can be seen in the graph as the slope of Poland's curve is negative. On the contrary, Spanish individuals show a slightly tendency to increase financial advice as the risk tolerance moves from low to high-risk tolerance. Getting different results for the two countries in this study shows the importance of uncertainty avoidance's moderating effect in this regard.

\section{Fig. 2: The moderating effect}

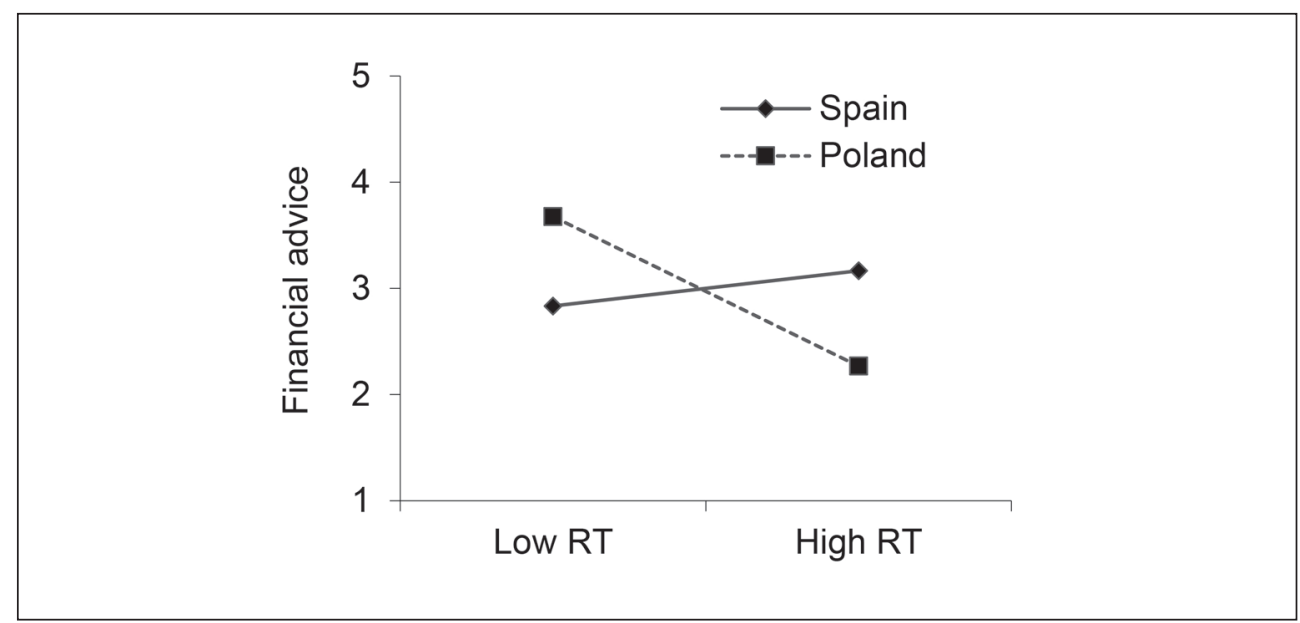




\section{Discussion}

The findings point to four main issues: financial behaviour as a function of financial attitude, knowledge and inclusion; the influence of financial literacy (its components) on financial advice; the effect of financial inclusion on financial advice; the role of culture in the relationship between risk tolerance and financial advice. The above set of relationships are discussed in the following paragraphs.

Firstly, it was demonstrated that financial behaviour is positively influenced by financial attitude, knowledge and inclusion, meaning that the latter factors do shape the individuals' behaviour, in particular, the one's behaviour related to financial matters. Hence, policymakers, educational institutions and the management teams of financial industry are recommended to design such curriculum and policies so to equip individuals with sound financial knowledge and awareness. This insight is crucial especially in the context of a post-communist transition country. These findings are in line with previous studies (Çera, Khan, Mlouk, et al., 2020; Fessler et al., 2019; Garg \& Singh, 2018; Potrich et al., 2016).

Secondly, the analysis highlights that financial literacy partly influences on financial advice, since one financial literacy's component was found to be insignificant (financial knowledge). Hence, financial attitude and behaviour positively affect one's financial advice, while financial knowledge does not impact financial advice. The above results underline the importance of financial attitude and behaviour in seeking advice from the others about financial matters, as identified by other authors (Moreland, 2018; Sherraden et al., 2015).

Thirdly, results of the analysis have shown that financial advice is positively affected by financial inclusion. As it was hypothesized, between one's financial inclusion and financial advice are related, since financial inclusion leads to financial advice. In general, financial regulations encourage financial institutions to give financial advice to their clients (Gerrans \& Hershey, 2014; Inderst \& Ottaviani, 2012). Such regulations under the ambit of the financial system can be complimented with various financial literacy enhancement programs. These regulations can also influence the behaviour of individuals and financial advice.

Finally, this article has demonstrated the role of culture in the effect of risk tolerance on financial advice. Culture is represented by uncertainty avoidance, which is one dimension of the Hofsted's (2010) culture. Findings of this work has shown that financial advice and risk tolerance reflect a negative association for individuals from Poland, whereas for those from Spain it is a slightly positive association. According to Hofsted's index, individuals from Poland manifest a very high preference for avoiding uncertainty, while individuals from Spain have not such very high preference. Considering the above discussion, one can conclude that culture is an important factor in the linkage between risk tolerance and financial advice. Given this finding, it can be said that if a financial literacy programmes will be designed and deliver, not same results will be gain across countries, in particular related to the relationship between risk tolerance and financial advice, since countries manifest differences in culture.

\section{Study Implications}

This paper offers theoretical application and practical implications. On the note of theoretical contribution of the article, the most important thing is that one can identify the moderation effect of culture on the effect of risk tolerance on financial advice as an essential factor to be considered in studying financial literacy puzzle in an international context. This insight leads to the modification of the used conceptual framework by the scholars in talking determinants financial literacy, capability and/or satisfaction and their effects.

On the note of practical implications, the article provides useful insights for governments, public-policy promoters, educational institutions, and financial industry to design strategies/ policies aimed at improving individuals' financial literacy and inclusion. They are recommended to embrace or design new syllabi, rules, and plans in order to include individuals in financial service system and develop financial literacy. Central banks and other financial institutions across the Europe have established partnerships with local educational institutions by introducing initiatives based on the online management and virtual portfolio of securities. By doing so, people can gain knowledge related to financial products and markets. Moreover, in such initiatives, there is the possibility experience investing in securities (OECD, 2016).

The research is not free of its limitations. Firstly, this paper is conducted in two European 
country and this limits its findings' generalisation to other contexts, in particular, regarding the culture effect. However, the replication of the conceptual framework applied in this article, can contribute to its validity by including in the analysis more countries. Secondly, selfreporting on selected indicators was applied as a way to collect the data. Hence, a respondent's answer was subject to recall (Xiao et al., 2014). This limitation can be overcome by using financial diaries as a tool to collect data and information is (Potocki \& Cierpiał-Wolan, 2019).

\section{References}

Agarwalla, S. K., Barua, S. K., Jacob, J., \& Varma, J. R. (2015). Financial Literacy among Working Young in Urban India. World Development, 67, 101-109. https://doi. org/10.1016/j.worlddev.2014.10.004

Ajzen, I. (1991). The theory of planned behavior. Organizational Behavior and Human Decision Processes, 50(2), 179-211. https:// doi.org/10.1016/0749-5978(91)90020-T

Allgood, S., \& Walstad, W. B. (2016). The effects of perceived and actual financial literacy on financial behaviors. Economic Inquiry, 54(1), 675-697. https://doi.org/10.1111/ecin.12255

Amaral, C., \& Kolsarici, C. (2020). The financial advice puzzle: The role of consumer heterogeneity in the advisor choice. Journal of Retailing and Consumer Services, 54, 102014. https://doi.org/10.1016/j. jretconser.2019.102014

Aprea, C., Wuttke, E., Breuer, K., Koh, N. K., Davies, P., Greimel-Fuhrmann, B., \& Lopus, J. S. (2016). International Handbook of Financial Literacy. Singapore: Springer. https:// doi.org/10.1007/978-981-10-0360-8

Arifin, A. Z. (2018). Influence of financial attitude, financial behavior, financial capability on financial satisfaction. In Proceedings of the 15th International Symposium on Management (INSYMA 2018) (pp. 100-103). https://doi. org/10.2991/insyma-18.2018.25

Atkinson, A., \& Messy, F.-A. (2012). Measuring Financial Literacy: Results of the OECD/International Network on Financial Education (INFE) Pilot Study (Working Papers on Finance, Insurance and Private Pensions, No. 15). Paris: OECD Publishing. https://doi. org $/ 10.1787 / 5 \mathrm{k} 9 \mathrm{csfs} 90 \mathrm{fr} 4-\mathrm{en}$

Atkinson, A., \& Messy, F.-A. (2013). Promoting Financial Inclusion through Financial Education: OECD/INFE Evidence,
Policies and Practice (OECD Working Papers on Finance, Insurance and Private Pensions, No. 34). Paris: OECD Publishing. https://doi. org/10.1787/5k3xz6m88smp-en

Bagozzi, R. P., \& Yi, Y. (2012). Specification, evaluation, and interpretation of structural equation models. Journal of the Academy of Marketing Science, 40(1), 8-34. https://doi. org/10.1007/s11747-011-0278-X

Beckett, A., Hewer, P., \& Howcroft, B. (2000). An exposition of consumer behaviour in the financial services industry. International Journal of Bank Marketing, 18(1), 15-26. https://doi.org/10.1108/02652320010315325

Belás, J., Nguyen, A., Smrčka, L., Kolembus, J., \& Cipovová, E. (2016). Financial Literacy of Secondary School Students. Case Study from the Czech Republic and Slovakia. Economics and Sociology, 9(4), 191-206. https://doi. org/10.14254/2071-789X.2016/9-4/12

Braunstein, S., \& Welch, C. (2002). Financial literacy: An overview of practice, research, and policy. Federal Reserve Bulletin, 88(11), 445-457. https://doi.org/10.17016/ bulletin.2002.88-11

Calcagno, R., \& Monticone, C. (2015). Financial literacy and the demand for financial advice. Journal ofBanking \& Finance, 50, 363-380. https://doi.org/10.1016/j.jbankfin.2014.03.013

Callan, V., \& Johnson, M. (2002). Some guidelines for financial planners in measuring and advising clients about their levels of risk tolerance. Journal of Personal Finance, 1(1), 31-44.

Castro-González, S., Fernández-López, S., Rey-Ares, L., \& Rodeiro-Pazos, D. (2020). The Influence of Attitude to Money on Individuals' Financial Well-Being. Social Indicators Research, 148(3), 747-764. https:// doi.org/10.1007/s11205-019-02219-4

Çera, G., Khan, K. A., Belas, J., \& Ribeiro, H. N. R. (2020). The Role of Financial Capability and Culture in Financial Satisfaction. Economic Papers: A Journal of Applied Economics and Policy, 39(4), 389-406. https:// doi.org/10.1111/1759-3441.12299

Çera, G., Khan, K. A., Mlouk, A., \& Brabenec, T. (2020). Improving financial capability: the mediating role of financial behaviour. Economic Research - Ekonomska Istraživanja, 1265-1282. https://doi.org/10.108 0/1331677X.2020.1820362

Chauhan, Y., \& Dey, D. K. (2020). Does financial literacy affect the value of financial 
advice? A contingent valuation approach. Journal of Behavioral and Experimental Finance, 25, 100268. https://doi.org/10.1016/j. jbef.2020.100268

Chu, Z., Wang, Z., Xiao, J. J., \& Zhang, W. (2017). Financial Literacy, Portfolio Choice and Financial Well-Being. Social Indicators Research, 132(2), 799-820. https://doi. org/10.1007/s11205-016-1309-2

Cliff, A., Babiarz, P., \& Woodyard, A. (2012). The demand for financial professionals' advice: The role of financial knowledge, satisfaction and confidence. Financial Services Review, 21(4), 291-305.

Collins, J. M. (2012). Financial Advice: A Substitute for Financial Literacy? Financial Services Review, 21(4), 307-322. https://doi. org/10.2139/ssrn.2046227

Crotty, J. (2009). Structural causes of the global financial crisis: A critical assessment of the 'new financial architecture'. Cambridge Journal of Economics, 33(4), 563-580. https:// doi.org/10.1093/cje/bep023

Cwynar, A., Cwynar, W., Kowerski, M., Filipek, K., \& Szuba, P. (2020). Debt literacy and debt advice-seeking behaviour among Facebook users: the role of social networks. Baltic Journal of Economics, 20(1), 1-33. https:// doi.org/10.1080/1406099x.2019.1693142

Fernandes, D., Lynch, J. G., \& Netemeyer, R. G. (2014). Financial literacy, financial education, and downstream financial behaviors. Management Science, 60(8), 1861-1883. https://doi.org/10.1287/mnsc.2013.1849

Fessler, P., Silgoner, M., \& Weber, R. (2019). Financial knowledge, attitude and behavior: evidence from the Austrian Survey of Financial Literacy. Empirica, 47(2), 929-947. https://doi. org/10.1007/s10663-019-09465-2

FINRA. (2012). National Financial Capability Study Military Survey. Financial Industry Regulatory Authority Investor Education Foundation. Retrieved from https://www.usfinancialcapability.org/

Fünfgeld, B., \& Wang, M. (2009). Attitudes and behaviour in everyday finance: evidence from Switzerland. International Journal of Bank Marketing, 27(2), 108-128. https://doi. org/10.1108/02652320910935607

Garg, N., \& Singh, S. (2018). Financial literacy among youth. International Journal of Social Economics, 45(1), 173-186. https://doi. org/10.1108/IJSE-11-2016-0303

Georgarakos, D., \& Inderst, R. (2011). Financial advice and Stock Market participation
(Working Paper No. 1296). Frankfurt am Mein: European Central Bank.

Gerrans, P., \& Hershey, D. A. (2014). Financial Adviser Anxiety, Financial Literacy and Financial Advice Seeking. SSRN Electronic Journal, 1-39. https://doi.org/10.2139/ ssrn.2413095

Glasman, L. R., \& Albarracín, D. (2006). Forming attitudes that predict future behavior: A meta-analysis of the attitude-behavior relation. Psychological Bulletin, 132(5), 778-822. https:// doi.org/10.1037/0033-2909.132.5.778

Grable, J., \& Lytton, R. H. (1999). Financial risk tolerance revisited: the development of a risk assessment instrument. Financial Services Review, 8(3), 163-181. https://doi. org/10.1016/s1057-0810(99)00041-4

Grable, J. E., \& Roszkowski, M. J. (2008). The influence of mood on the willingness to take financial risks. Journal of Risk Research, 11(7), 905-923. https://doi. org/10.1080/13669870802090390

Hair, J. F., Hult, G. T. M., Ringle, C. M., \& Sarstedt, M. (2017). A Primer on Partial Least Squares Structural Equation Modeling (PLSSEM) (2nd ed.). Sage Publications.

Hair, J. F., Risher, J. J., Sarstedt, M., \& Ringle, C. M. (2019). When to use and how to report the results of PLS-SEM. European Business Review, 31(1), 2-24. https://doi. org/10.1108/EBR-11-2018-0203

Hanna, S. D., Waller, W., \& Finke, M. S. (2011). The Concept of Risk Tolerance in Personal Financial Planning. Journal of Personal Finance, 7(1), 96-108. https://doi. org/10.2139/ssrn.1923409

Henager, R., \& Cude, B. J. (2019). Financial Literacy of High School Graduates: Long- and Short-Term Financial Behavior by Age Group. Journal of Family and Economic Issues, 40(3), 564-575. https://doi.org/10.1007/s10834-01909626-2

Henchoz, C., Coste, T., \& Wernli, B. (2019). Culture, money attitudes and economic outcomes. Swiss Journal of Economics and Statistics, 155(1), 1-13. https://doi.org/10.1186/ s41937-019-0028-4

Henseler, J., Ringle, C. M., \& Sarstedt, M. (2015). A new criterion for assessing discriminant validity in variance-based structural equation modeling. Journal of the Academy of Marketing Science, 43(1), 115-135. https://doi. org/10.1007/s11747-014-0403-8 
Hermansson, C. (2015). Understanding the relationships between bank-customer relations, financial advisory services and saving behavior (Doctoral Dissertation). KTH Royal Institute of Technology, Stockholm.

Hofstede, G. (2001). Comparing Values, Behaviors, Institutions and Organizations Across Nations. Thousand Oaks, CA: Sage.

Hofstede, G., \& Hofstede, G. J. (1991). Cultures and Organizations: Software of the Mind (2nd ed.). New York, NY: McGraw-Hill.

Hofstede, G., Hofstede, G. J., \& Minkov, M. (2010). Cultures and Organizations: Software of the Mind, Intercultural Cooperation and Its Importance for Survival (3rd ed.). New York, NY: McGraw-Hill.

Huston, S. J. (2010). Measuring Financial Literacy. Journal of Consumer Affairs, 44(2), 296-316. https://doi.org/10.1111/j.17456606.2010.01170.x

Inderst, R., \& Ottaviani, M. (2012). Financial advice. Journal of Economic Literature, 50(2), 494-512. https://doi.org/10.1257/jel.50.2.494

Irving, K. (2012). The Financial Life WellLived: Psychological Benefits of Financial Planning. Australasian Accounting, Business and Finance Journal, 6(4), 47-59.

Jang, S., Shen, W., Allen, T. D., \& Zhang, H. (2018). Societal individualism-collectivism and uncertainty avoidance as cultural moderators of relationships between job resources and strain. Journal of Organizational Behavior, 39(4), 507524. https://doi.org/10.1002/job.2253

Jeong, W.-Y., \& Hanna, S. D. (2004). Risk Tolerance and Financial Satisfaction. International Journal of Human Ecology, 5(1), 35-43.

Johnson, E., \& Sherraden, M. S. (2007). From Financial Literacy to Financial Capability Among Youth. The Journal of Sociology \& Social Welfare, 34(3), 119-147.

Joo, S., \& Grable, J. (2004). An Exploratory Framework of the Determinants of Financial Satisfaction. Journal of Family and Economic Issues, 25(1), 25-50. https://doi.org/10.1023/ B:JEEI.0000016722.37994.9f

Kalmi, P. (2018). The Effects of Financial Education: Evidence from Finnish Lower Secondary Schools. Economic Notes, 47(2-3), 353-386. https://doi.org/10.1111/ecno.12114

Karabulut, Y. (2012). Financial Advice: An Improvement for Worse? SSRN Electronic Journal. https://doi.org/10.2139/ssrn.1710634

Kempson, E., Perotti, V., \& Scott, K. (2013). Measuring Financial Capability:
A New Instrument and Results from Low- and Middle-Income Countries (Working Paper). Washington, DC: World Bank.

Khan, K. A., \& Akhtar, M. A. (2020). Electronic payment system use: a mediator and a predictor of financial satisfaction. Investment Management and Financial Innovations, 17(3), 246-262. https://doi.org/10.21511/ imfi.17(3).2020.19

Khan, K. A., Çera, G., \& Netek, V. (2019). Perception of the Selected Business Environment Aspects by Service Firms. Journal of Tourism and Services, 10(19), 111-127. https://doi.org/10.29036/jots.v10i19.115

Kim, K. T., Anderson, S. G., \& Seay, M. C. (2019). Financial Knowledge and ShortTerm and Long-Term Financial Behaviors of Millennials in the United States. Journal of Family and Economic Issues, 40(2), 194-208. https://doi.org/10.1007/s10834-018-9595-2

Kim, K. T., Pak, T.-Y., Shin, S. H., \& Hanna, S. D. (2018). The relationship between financial planner use and holding a retirement saving goal: A propensity score matching analysis. Financial Planning Review, 1(1-2), e1008. https://doi.org/10.1002/cfp2.1008

Klapper, L., Lusardi, A., \& van Oudheusden, P. (2014). Financial Literacy Around the World: Insight from the Standards \& Poor's Ratings Services Global Financial Literacy Survey (Report). Washington, DC: Global Financial Literacy Excellence Center (GFLEC).

Klapper, L., Lusardi, A., \& van Oudheusden, P. (2015). Financial literacy around the world: Insights from the Standard \& Poor's Ratings Services Global Financial Literacy Survey (Report). Washington, DC: World Bank. Retrieved from http://www.openfininc.org/ wp-content/uploads/2016/04/2015-Finlit_ paper_17_F3_SINGLES.pdf

Kramer, M. M. (2016). Financial literacy, confidence and financial advice seeking. Journal of Economic Behavior \& Organization, 131 (Part A), 198-217. https://doi.org/10.1016/J. JEBO.2016.08.016

Kreiser, P. M., Marino, L. D., Dickson, P., \& Weaver, K. M. (2010). Cultural Influences on Entrepreneurial Orientation: The Impact of National Culture on Risk Taking and Proactiveness in SMEs. Entrepreneurship: Theory and Practice, 34(5), 959-983. https:// doi.org/10.1111/j.1540-6520.2010.00396.x

LeFebvre, R., \& Franke, V. (2013). Culture Matters: Individualism vs. Collectivism in 
Conflict Decision-Making. Societies, 3(1), 128-146. https://doi.org/10.3390/soc3010128

Lerner, J. S., Small, D. A., \& Loewenstein, G. (2004). Heart strings and purse strings: Carryover effects of emotions on economic decisions. Psychological Science, 15(5), 337-341. https:// doi.org/10.1111/j.0956-7976.2004.00679.x

Liu, F., Yilmazer, T., Loibl, C., \& Montalto, C. (2019). Professional financial advice, selfcontrol and saving behavior. International Journal of Consumer Studies, 43(1), 23-34. https://doi.org/10.1111/ijcs. 12480

Lusardi, A., \& Mitchell, O. S. (2014). The Economic Importance of Financial Literacy: Theory and Evidence. Journal of Economic Literature, 52(1), 5-44. https://doi.org/10.1257/jel.52.1.5

Lusardi, A., \& Mitchelli, O. S. (2007). Financial Literacy and Retirement Preparedness: Evidence and Implications for Financial Education. Business Economics, 42(1), 35-44. https://doi.org/10.2145/20070104

Matis, E. A., Matis, C. D., \& Strouhal, J. (2013). Risk management debate focused on banking industry. International Journal of Entrepreneurial Knowledge, 1(1). https://doi. org/10.37335/ijek.v111.9

Moreland, K. A. (2018). Seeking Financial Advice and Other Desirable Financial Behaviors. Journal of Financial Counseling and Planning, 29(2), 198-206. https://doi. org/10.1891/1052-3073.29.2.198

Mueller, S. L., \& Thomas, A. S. (2001). Culture and entrepreneurial potential: A nine country study of locus of control and innovativeness. Journal of Business Venturing, 16(1), 51-75. https://doi.org/10.1016/S0883-9026(99)00039-7

Nguyen, L. T. M., Gallery, G., \& Newton, C. (2016). The Influence of Financial Risk Tolerance on Investment Decision-Making in a Financial Advice Context. Australasian Accounting, Business and Finance Journal, 10(3), 3-22. https://doi.org/10.14453/aabfj.v10i3.2

Nguyen, T. A. N., \& Rozsa, Z. (2019). Financial Literacy and Financial Advice Seeking for Retirement Investment Choice. Journal of Competitiveness, 11(1), 70-83. https://doi. org/10.7441/joc.2019.01.05

Odongo, I. (2016). The Influence of Culture on Judgment and Decision Making. International Journal of Advanced Legal Studies and Governance, 6(1), 1-21.

OECD. (2013). Financial Literacy and Inclusion. In Financial Literacy \& Education. Paris: OECD Publishing.
OECD. (2016). Financial Education in Europe: Trends and Recent Developments. Paris: OECD Publishing. https://doi. org/10.1787/9789264254855-en

Ozili, P. K. (2018). Impact of digital finance on financial inclusion and stability. Borsa Istanbul Review, 18(4), 329-340. https://doi. org/10.1016/j.bir.2017.12.003

Pan, X., Wu, W., \& Zhang, X. (2020). Is financial advice a cure-all or the icing on the cake for financial literacy? Evidence from financial market participation in China. International Review of Financial Analysis, 69(16), 101473. https://doi.org/10.1016/j.irfa.2020.101473

Perry, V. G., \& Morris, M. D. (2005). Who Is in Control? The Role of Self-Perception, Knowledge, and Income in Explaining Consumer Financial Behavior. Journal of Consumer Affairs, 39(2), 299-313. https://doi. org/10.1111/j.1745-6606.2005.00016.x

Podsakoff, P. M., MacKenzie, S. B., Lee, J.Y., \& Podsakoff, N. P. (2003). Common method biases in behavioral research: A critical review of the literature and recommended remedies. Journal of Applied Psychology, 88(5), 879-903. https://doi.org/10.1037/0021-9010.88.5.879

Potocki, T., \& Cierpiał-Wolan, M. (2019). Factors shaping the financial capability of lowincome consumers from rural regions of Poland. International Journal of Consumer Studies, 43(2), 187-198. https://doi.org/10.1111/ijcs.12498

Potrich, A. C. G., Vieira, K. M., \& Kirch, G. (2015). Determinants of Financial Literacy: Analysis of the Influence of Socioeconomic and Demographic Variables. Revista Contabilidade \& Finanças, 26(69), 362-377. https://doi. org/10.1590/1808-057x201501040

Potrich, A. C. G., Vieira, K. M., \& Kirch, G. (2018). How well do women do when it comes to financial literacy? Proposition of an indicator and analysis of gender differences. Journal of Behavioral and Experimental Finance, 17, 2841. https://doi.org/10.1016/J.JBEF.2017.12.005

Potrich, A. C. G., Vieira, K. M., \& MendesDa-Silva, W. (2016). Development of a financial literacy model for university students. Management Research Review, 39(3), 356376. https://doi.org/10.1108/MRR-06-20140143

Přívara, A., \& Kiner, A. (2020). Immigrant Employment in the Slovak Hospitality Industry: Profiles, Experience, and Education. Journal of Tourism and Services, 11(21), 166-182. https:// doi.org/10.29036/jots.v11i21.223 
Rai, K., Dua, S., \& Yadav, M. (2019). Association of Financial Attitude, Financial Behaviour and Financial Knowledge Towards Financial Literacy: A Structural Equation Modeling Approach. FIIB Business Review, 8(1), 51-60. https://doi. org/10.1177/2319714519826651

Randáková, M., \& Bokšová, J. (2016). Repayment plan as essential instrument in personal bankruptcy in the Czech Republic. International Journal of Entrepreneurial Knowledge, 4(2). https://doi.org/10.37335/ijek. v4i2.44

Reyers, M. (2019). Financial capability and emergency savings among South Africans living above and below the poverty line. International Journal of Consumer Studies, 43(4), 335-347. https://doi.org/10.1111/ijcs. 12520

Riau, S. T. I. E. (2019). The Effect of Financial Inclusion and Banking Behavior on Household Debt Behavior. JEBI (Jurnal Ekonomi Dan Bisnis Islam), 4(1), 51. https://doi. org/10.15548/jebi.v4i1.205

Ringle, C. M., Wende, S., \& Becker, J.-M. (2015). SmartPLS (3.0). http://www.smartpls.com

Robb, C. A., \& Woodyard, A. S. (2011). Financial Knowledge and Best Practice Behavior. Journal of Financial Counseling and Planning, 22(1), 60-70.

Sample, J., \& Warland, R. (2018). Attitude and Prediction of Behavior. Social Forces, 51(3), 292-304. https://doi.org/10.1093/ $\mathrm{sf} / 51.3 .292$

Santini, F. D. O., Ladeira, W. J., Mette, F. M. B., \& Ponchio, M. C. (2019). The antecedents and consequences of financial literacy: a meta-analysis. International Journal of Bank Marketing, 37(6), 1462-1479. https://doi. org/10.1108/IJBM-10-2018-0281

Serido, J., Shim, S., \& Tang, C. (2013). A developmental model of financial capability: A framework for promoting a successful transition to adulthood. International Journal of Behavioral Development, 37(4), 287-297. https://doi.org/10.1177/0165025413479476

Sherraden, M. S. (2013). Building Blocks of Financial Capability. In J. Birkenmaier, M. Sherraden, \& J. Curley (Eds.), Financial Capability and Asset Development (pp. 3-43). Oxford: Oxford University Press. https://doi.org/10.1093/ acprof:oso/9780199755950.003.0012

Sherraden, M. S., \& Ansong, D. (2016). Financial Literacy to Financial Capability:
Building Financial Stability and Security. In C. Aprea, E. Wuttke, K. Breuer, N. K. Koh, P. Davies, B. Greimel-Fuhrmann, \& J. S. Lopus (Eds.), International Handbook of Financial Literacy (pp. 83-96). Singapore: Springer. https://doi.org/10.1007/978-981-10-0360-8_7

Sherraden, M. S., Huang, J., Jacobson Frey, J., Birkenmaier, J., Callahan, C., Clancy, M. M., \& Sherraden, M. (2015). Financial Capability and Asset Building for All. St. Louis, MO: American Academy of Social Work and Social Welfare.

Shkvarchuk, L., \& Slav'yuk, R. (2019). The Financial Behavior of Households in Ukraine. Journal of Competitiveness, 11(3), 144-159. https://doi.org/10.7441/joc.2019.03.09

Smith, P. B., Peterson, M. F., Schwartz, S. H., Ahmad, A. H., Akande, D., Andersen, J. A., Ayestaran, S., Bochner, S., Callan, V., Davila, C., Ekelund, B., François, P. H., Graversen, G., Harb, C., Jesuino, J., Kantas, A., Karamushka, L., Koopman, P., Leung, K., ... Yanchuk, V. (2002). Cultural Values, Sources of Guidance, and their Relevance to Managerial Behavior: A 47-Nation Study. Journal of Cross-Cultural Psychology, 33(2), 188-208. https://doi. org/10.1177/0022022102033002005

Statman, M. (2010). The Cultures of Risk Tolerance. SSRN Electronic Journal. https:// doi.org/10.2139/ssrn.1647086

Stolper, O. (2018). It takes two to Tango: Households' response to financial advice and the role of financial literacy. Journal of Banking and Finance, 92, 295-310. https://doi. org/10.1016/j.jbankfin.2017.04.014

Stolper, O., \& Walter, A. (2017). Financial literacy, financial advice, and financial behavior. Journal of Business Economics, 87(5), 581-643. https://doi.org/10.1007/s11573-017-0853-9

Tang, N., \& Lachance, M.-E. (2012). Financial advice and trust. Financial Services Review, 21(3), 209-226.

Taylor, M. (2011). Measuring Financial Capability and its Determinants Using Survey Data. Social Indicators Research, 102(2), 297314. https://doi.org/10.1007/s11205-010-9681-9

Vieira, K. M., Potrich, A. C. G., \& MendesDa-Silva, W. (2019). A Financial Literacy Model for University Students. In W. Mendes-Da-Silva (Ed.), Individual Behaviors and Technologies for Financial Innovations (pp. 69-95). Cham: Springer. https://doi.org/10.1007/978-3-319-91911-9_4

Von Gaudecker, H. M. (2015). How Does Household Portfolio Diversification Vary with 
Financial Literacy and Financial Advice? Journal of Finance, 70(2), 489-507. https://doi. org/10.1111/jofi.12231

Wang, M., \& Shi, J. (2014). Psychological Research on Retirement. Annual Review of Psychology, 65(1), 209-233. https://doi. org/10.1146/annurev-psych-010213-115131

Westermann, S., Niblock, S. J., Harrison, J. L., \& Kortt, M. A. (2020). Financial Advice Seeking: A Review of the Barriers and Benefits. Economic Papers: A Journal of Applied Economics and Policy, 39(4), 367-388. https:// doi.org/10.1111/1759-3441.12294

Winchester, D. D., \& Huston, S. J. (2015). All Financial Advice for the Middle Class is Not Equal. Journal of Consumer Policy, 38(3), 247-264. https://doi.org/10.1007/s10603-0159290-8

Worimegbe, P. M., Worimegbe, T. M., \& Abiola-Oke, E. (2020). Gamification and Customers Experience in the Hospitality Industry. Journal of Tourism and Services, 11(21), 71-87. https://doi.org/10.29036/jots. v11i21.165

Xiao, J. J., Ahn, S. Y., Serido, J., \& Shim, S. (2014). Earlier financial literacy and later financial behaviour of college students. International Journal of Consumer Studies, 38(6), 593-601. https://doi.org/10.1111/ijcs.12122

Xiao, J. J., \& O'Neill, B. (2016). Consumer financial education and financial capability. International Journal of Consumer Studies, 40(6), 712-721. https://doi.org/10.1111/ijcs.12285
Yaniv, I. (2004). Receiving other people's advice: Influence and benefit. Organizational Behavior and Human Decision Processes, 93(1), 1-13. https://doi.org/10.1016/j.obhdp.2003.08.002

Yao, R., Gutter, M. S., \& Hanna, S. D. (2005). The financial risk tolerance of Blacks, Hispanics and Whites. Journal of Financial Counseling and Planning, 16(1), 51-62.

Yap, R. J. C., Komalasari, F., \& Hadiansah, I. (2018). The Effect of Financial Literacy and Attitude on Financial Management Behavior and Satisfaction. Bisnis \& Birokrasi: Journal IImu Administrasi dan Organisasi, 23(3), 140146. https://doi.org/10.20476/jbb.v23i3.9175

Yong, C. C., Yew, S. Y., \& Wee, C. K. (2018). Financial knowledge, attitude and behaviour of young working adults in Malaysia. Institutions and Economies, 10(4), 21-48.

Yoong, J. K., \& Hung, A. A. (2010). Asking for Help Survey and Experimental Evidence Change (Labor and Population Working Paper WR-714-1). Santa Monica, CA: RAND Corporation. https://doi.org/10.7249/WR714-1

Zamir, Z. (2019). The Impact of Knowledge Capture and Knowledge Sharing on Learning, Adaptability, Job Satisfaction and Staying Intention. International Journal of Entrepreneurial Knowledge, 7(1), 46-64. https://doi.org/10.37335/ijek.v7i1.87

Zins, A., \& Weill, L. (2016). The determinants of financial inclusion in Africa. Review of Development Finance, 6(1), 46-57. https://doi. org/10.1016/j.rdf.2016.05.001 